\title{
Software, para que te quero
}

CÔRTE, Adelaide Ramos e, ALMEIDA, lêda Muniz de (Coords.). Avaliação de softwares para bibliotecas. São Paulo : Polis, APB, 2000. 108p.
A escrita é uma das formas das manifestações humanas que mais marcam o perfil do ser humano. Cada autor define-se (inconscientemente) por um tipo de escrita. E é reconhecida pela forma da escrita. É como o perfume de cada um dos indivíduos. Assim é Adelaide Ramos e Côrte, que na literatura da biblioteconomia definiu-se (inconscientemente?) por uma contribuição técnica voltada para padrões específicos.

No seu primeiro livro, Biblioteconomia: legislação e órgãos de classe, compilou de forma competente toda a legislação pertinente à biblioteconomia e legou à profissão um manual da legislação profissional que minimiza o tempo de pesquisa e maximiza as informações legislativas. Já não se precisa correr atrás de diários e similares. Tudo está posto em um só documento.
Agora, na sua segunda incursão literária, A. R. e CÔRTE, associada a lêda Muniz de ALMEIDA, insere na lista dos livros importantes para a biblioteconomia, documentação e ciência da informação o Avaliação de softwares para bibliotecas. Embora seja um assunto na pauta do dia, residia na área uma lacuna a respeito do tema software para bibliotecas. Residia, pois que com o lançamento do Avaliação ... a lacuna foi preenchida.

Quem esteve, ou está envolvido com o processo de automação de uma biblioteca entende os problemas e os desafios que se apresentam, reforçados pela falta de avaliação e de aconselhamento, primeiro sobre os softwares existentes e posteriormente sobre qual escolher, problemas esses que se apresentam, também por falta de planejamento que não identifica previamente alguns aspectos imprescindíveis para um bom resultado. 
Côrte \& Almeida vêm facilitar o trabaIho de bibliotecários envolvidos com essa escolha, analisando oito softwares para automação de bibliotecas e mais três de informação legislativa. A análise, produto por produto, inclui: características da empresa detentora do programa, características do software, e visão do cliente (empresa que já roda o programa). Informa os clientes que possuem os softwares analisados, pelos quais pode ser verificadas a idoneidade da empresa que detém/fornece o produto.

Muito embora, a leitura de quadros seja sempre um processo ortodoxo, os quadros demonstrativos das avaliações apresentados perfilam-se como leitura fluente e imprescindível, pela riqueza nos detalhes das avaliações, que vão desde os requisitos relacionados à tecnologia (de cada software), até os requisitos relacionados ao processo gerencial, passando pelos gerais e obrigatórios exigidos pela biblioteca.

Fazem a avaliação geral de cada software, informando dados como: existência de níveis diferenciados de acesso aos documentos, alimentação de dados via online, importação de dados de outras bases, diferenciação entre usuários pessoais e institucionais, auditoria no sistema, código de partes, entre muitos outros.

Informam sobre treinamento, instalação, testes, garantias, suporte técnico e manutenção prestados por cada empresa responsável pelo programa.
Abordam a Conversão Retrospectiva (passagem do banco de dados já existente para a base de dados automatizada), um problema técnico conflituoso entre bibliotecários, responsáveis pelo órgão de informação, e os administradores da instituição. Os primeiros querem uma solução qualificada, por isso nem sempre rápida; os segundos anseiam por ver toda a base de dados automatizada, uma solução quantificada. Para as autoras o "trabalho de Conversão Retrospectiva - CR é considerado um trabalho intelectual e como tal deve merecer um projeto específico".

Concluem que é fundamental a interação entre bibliotecário e analista de sistemas e que "a escolha de um software é tarefa cooperativa, integrada e participativa entre esses profissionais, e constitui um dos grandes desafios para as bibliotecas e unidades de documentação e informação bibliográfica".

Um alerta das autoras, e que merece destaque, é sobre a importância que se deve dar ao processo de implantação de um software, que envolve certa complexidade e não se trata tão somente da instalação de um produto, mas sim da "implantação de uma nova filosofia de trabalho em que todas as atividades do ciclo documental estão refletidas".

Por tudo que fica escrito aqui, e muito mais que está no livro, ousamos dar um aviso a todos aqueles que estão iniciando ou prestes a iniciar a automação de acervos: Inf.Inf., Londrina, v. 5, n. 2, p. 151-153, jul./dez. 2000 
não deixem de ler esse livro. Ou melhor: não deixem de consultar esse manual sobre software para automação de bibliotecas.

Justino Alves Lima

Bibliotecário da UFS

\section{Title}

Software, Why Do I Want You?

\section{Titulo}

Software, para qué te quiero 